\title{
PENERAPAN ALGORITMA TRIPOD GAIT PADA ROBOT HEXAPOD MENGGUNAKAN ARDUINO MEGA128
}

\section{APPLICATION OF ALGORITHM OF THE TRIPOD GAIT ON A HEXAPOD ROBOTS USING ARDUINO MEGA128}

\author{
Andi Chairunnas \\ Fakultas Matematika dan Ilmu Pengetahuan Alam, Jurusan Ilmu Komputer Universitas Pakuan Bogor \\ Jalan Pakuan, Tegallega Bogor Tengah, Kota Bogor 16143, Indonesia \\ andi.chairunnas@yahoo.com \\ Naskah Diterima: 19 Juli 2017; Direvisi : 7 September 2017; Disetujui : 12 September 2017
}

\begin{abstract}
Abstrak
Pergerakan robot beroda yang menggunakan motor servo pada setiap kakinya dimana servo tersebut dikontrol untuk menggerakan kaki dari robot. Untuk dapat menggerakkan setiap sendi pada kaki robot biasanya menggunakan model matematika geometri yang dimplementasikan pada sistem kinematik robot. Pada penelitian ini akan dibahas bagaimana membangun sistem kendali pada robot hexapod dengan menerapkan pola langkah tripod gait pada robot hexapod sehingga akurasi pergerakan yang diterapkan pada robot hexapod akan menghasilkan pola gerakan yang maksimal. Pada pengujian gerakan maju pada area terbuka dan maju pada area tertutup dengan kecepatan rata-rata 5 $\mathrm{cm} / \mathrm{s}$, pengujian gerakan mundur pada area terbuka dan mundur pada area tertutup dengan kecepatan rata-rata 4.32 $\mathrm{cm} / \mathrm{s}$, pengujian gerakan berputar kanan pada terbuka dan berputar kanan pada tertutup dengan kecepatan rata-rata 13.44 derajat/detik, Pengujian gerakan berputar kiri pada terbuka dan berputar kiri pada tertutup dengan kecepatan ratarata 12.85 derajat/detik, daya yang dibutuhkan keseluruhan pengujian pada area terbuka dan area tertutup adalah 0.3 Volt dengan durasi keseluruhan pakai 240.8 detik.
\end{abstract}

Kata Kunci : Algoritma, Robot hexapod, Tripod Gait, Forward Kinematic

\begin{abstract}
The movement of robots by using a wheel that uses servo motors on each leg where the servo is controlled to move the legs of the robot. To be able to move every joint on the foot of the robot usually uses a mathematical model of geometry that is implemented on a robotic kinematic system. This research will be discussed on how to build a Hexapod robot control at the system by applying the pattern step tripod gait on a Hexapod robot so that the accuracy of movement applied on a Hexapod Robot will produce the maximal movement patterns. On testing the movement Forward in open areas and advanced on the Area Covered with an average speed of $5 \mathrm{~cm} / \mathrm{s}$, testing Motion backward on open areas and retreat in enclosed areas with an average speed of $4.32 \mathrm{~cm} / \mathrm{s}$, testing the rotary motion Right on open and Turning Right on Closed with an average speed of 13 degrees/minutes, testing the rotary motion of the left in the open and Turning left on Closed with an average speed of 12.85 degrees/sec The power needed, overall testing on areas of open and enclosed areas is 0.3 Volts with an overall duration of use 240.8 seconds.
\end{abstract}

Keywords: Hexapod, Robot Algorithm, a Tripod Gait, Forward Kinematic 


\section{PENDAHULUAN}

Pergerakan robot dengan menggunakan roda yang menggunakan motor servo pada setiap kakinya dimana servo tersebut dikontrol untuk menggerakan kaki dari robot. (Setiawan, 2015). Dengan menggunakan kinematika robot ini dapat didefinisikan sebagai pergerakan robot (motion) tanpa memperhatikan gaya (force) ataupun faktor lain yang mempengaruhi gerakan robot tersebut (Setiawan, 2015). Kinematika pada robot secara umum terbagi menjadi dua yakni forward kinematic dan inverse kinematic. Forward kinematic adalah analisis kinematic untuk mendapatkan koordinat posisi $(\mathrm{x}, \mathrm{y})$ dan orientasi dari robot tersebut jika diketahui sudut dari tiap sendi. Misalnya jika robot mempunyai n-DOF dan diketahui sudut dari tiap joint maka dapat digunakan analisis forward kinematic untuk mendapatkan koordinat posisi robot. Sedangkan inverse kinematic adalah analisis kinematik untuk mendapatkan besar sudut dan orientasi dari masing-masing sendi jika diketahui koordinat posisi (x, y) (Setiawan, 2015).

Dengan penerapan algoritma kinematika, akan menghasilkan sudut yang harus dibentuk masing- masing sendi agar menghasilkan gerakan selaras pada kaki robot. Kemudian untuk mengatur pergerakan semua kaki robot diperlukan adanya penerapan algoritma pola gerak (Munir, 2011). Algoritma yang telah lama berkembang di dunia robotika untuk mengontrol gerakan kaki robot hexapod adalah tripod gait dan wave gait (Isvara, 2010). Pada algoritma tripod gait tiga kaki robot mengayun dan tiga kaki menyentuh tanah secara bergantian untuk membuat robot berjalan, sedangakan pada algoritma wave gait kaki robot bergerak secara bergantian satu persatu seperti gelombang untuk membuat robot berjalan (Isvara, 2010). Pada penelitian ini akan membahas tentang penerapan Algoritma Tripod Gaid pada Robot Hexapod menggunakan Arduino Megal28 Inputnya merupakan nilai yang di inputkan di servo dan diolah menggunakan algoritma untuk menghasilkan pola gerak yang sesuai dengan gerakan pada kaki robot.

\section{METODE}

\section{Kerangka Konsep/Pola Pikir}

Pada penelitian yang dilakukan, pola pikir yang digunakan untuk menyelesaikan rumusan masalah dapat dilihat pada gambar berikut: 


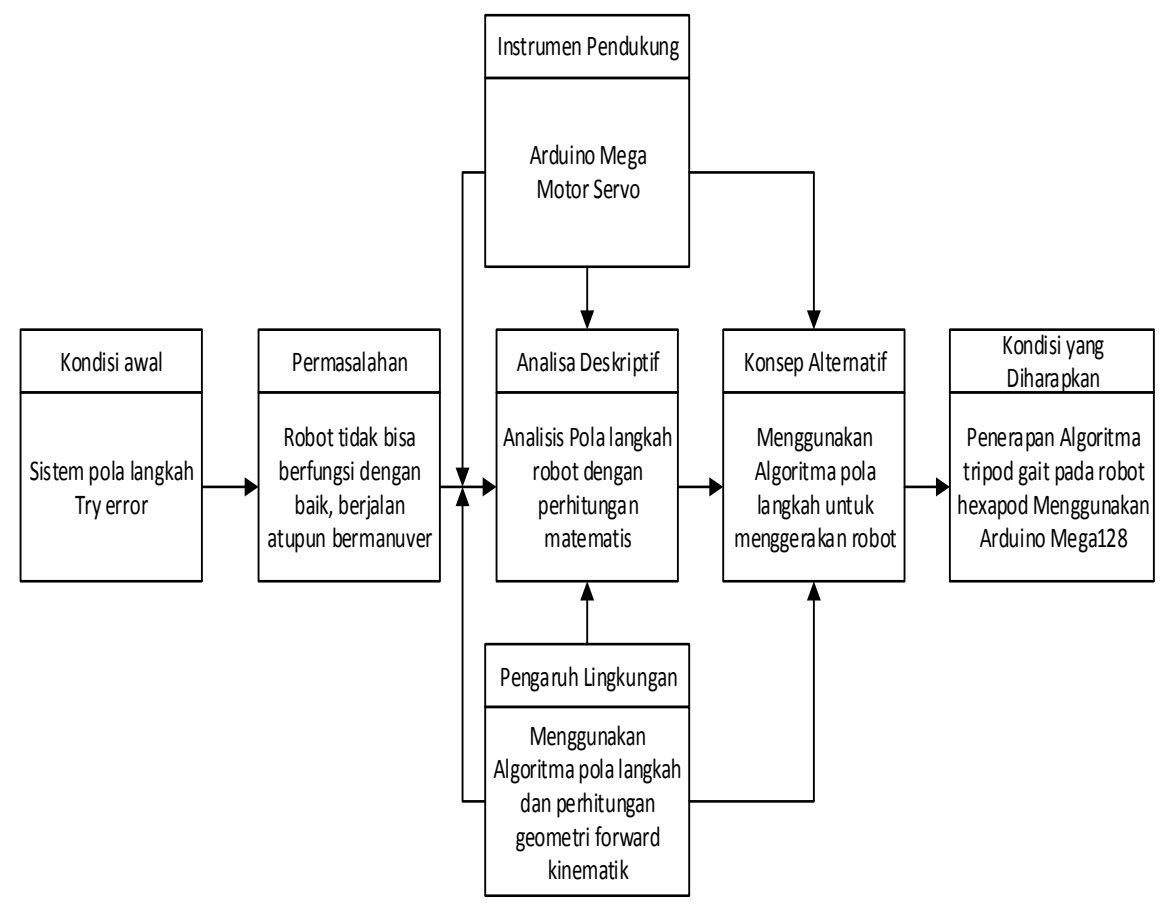

Gambar 1. Pola Pikir

Pola pikir dalam merumuskan permasalahan seperti pada gambar di atas memiliki faktor utama yaitu kondisi awal, permasalahan, instrument pendukung pengaruh lingkungan, analisa deskriptif, konsep alternatif, dan kondisi yang diharapkan (Harsono, 2012; Purwanto, 2009).

\section{Metode Pengumpulan Data}

dalam penelitian ini adalah pengamatan atau Observasi. Observasi adalah pengamatan dan pencatatan secara sistematis terhadap unsur-unsur yang tampak dalam suatu gejala atau gejala-gejala dalam objek penelitian. Proses pengumpulan data dilakukan melalui pengamatan dan penginderaan dengan cara mencatat dan mengamati langsung hasil dari alat yang dibuat berhasil atau tidak (Budiharto, 2010, 2014).

Hal lainnya yang diamati dan dicatat adalah akurasi realtime dari alat yang dibuat. Data yang diamati sebagai berikut:

Data sudut terdiri dari 2 data yaitu pertama data "sudut $\theta_{1}$ " dan "sudut $\theta_{2}$ " yang diinputkan secara manual melalu program, dan data kedua yaitu panjang dari link terdiri dari " $\mathrm{L}_{1}$ " dan " $\mathrm{L}_{2}$ " berfungsi untuk penopang setiap sudut dan mengetahui tinggi dari robot. Penjelasan dari kedua data tersebut adalah:

1. "sudut $\theta_{1}$ " merupakan nilai sudut DOF ke-1 atau sendi pertama untuk parameter pergerakan motor servo sehingga sudut pusat akan berubah.

2. "sudut $\theta_{2}$ " merupakan nilai sudut DOF ke-2 atau sendi kedua untuk parameter pergerakan motor servo sehingga sudut DOF ke-2 akan berubah.

3. " $\mathrm{L}_{1}$ " (Link) merupakan nilai panjang penopang untuk sendi "sudut $\theta_{1}$ ".

4. " $\mathrm{L}_{2}$ " (Link) merupakan nilai panjang penopang untuk sendi "sudut $\theta_{2}$ ".

Untuk data Link adalah data penopang setiap sendi dan untuk nilai sudut diinput berbeda setiap kakinya agar mendapatkan bentuk kaki yang diinginkan seperti saat berdiri dan angkat kaki. Dalam microsoft excel sudah dibuat simulasi 
bentuk kaki robot yang secara otomatis setiap perubahan data sudut maka akan berubah pula bentuk kakinya.

Proses pengolahan data sudut yang nantinya akan diproses sehingga mengasilkan nilai koordinat $(\mathrm{x}, \mathrm{y})$, yang berfungsi sebagai gambaran bentuk setiap titik sudut kaki robot (Dwi, Taufiq, 2010).

$\mathbf{L}_{\mathbf{1}}$ sebagai panjang dari Link pertama dan sudut $\theta_{1}$ sebagai poros pusat dan menghasilkan nilai koordinat $\left(x_{1}, y_{1}\right)$ untuk Link 1.

$x_{1}=L_{1} \cdot \cos \left(\theta_{1}\right) \ldots(1)$

$y_{1}=L_{1} \cdot \sin \left(\theta_{1}\right) \ldots$

Link 2 dengan $\left(x_{2}, y_{2}\right)$ yaitu $\mathbf{L}_{2}$ sebagai panjang dari Link kedua dan nilai sudut $\theta_{2}$ lalu digabungkan dengan nilai koordinat $\left(x_{1}, y_{1}\right)$ untuk Link 1.

$x_{2}=x_{1}+L_{2} \cdot \cos \left(\theta_{1}+\theta_{2}\right) \ldots .(3)$

$y_{2}=y_{1}+L_{2} \cdot \sin \left(\theta_{1}+\theta_{2}\right) \ldots(4)$

$\mathrm{L}_{1}=$ panjang Link 1

$\theta_{1}=$ sudut untuk Link 1

$\mathrm{L}_{2}=$ panjang Link 2

$\theta_{2}=$ sudut untuk Link 2

\section{Metode Pengembangan Sistem}

Metode pengembangan sistem ini didasarkan pada teknik analisa kinematik forward kinematic dan tripod gait. Forward kinematic merupakan proses pengolahan nilai sudut sebagai data input untuk dijadikan parameter siku atau sudut setiap masing-masing kaki robot, yang nantinya akan terbentuk sebuah bentuk kaki yang akan dipakai saat bergerak. Tripod gait digunakan sebagai proses penggambaran pola gerakan robot. Hasil dari proses ini adalah untuk berjalan dan bermanuver robot hexapod (Munadi, 2013).

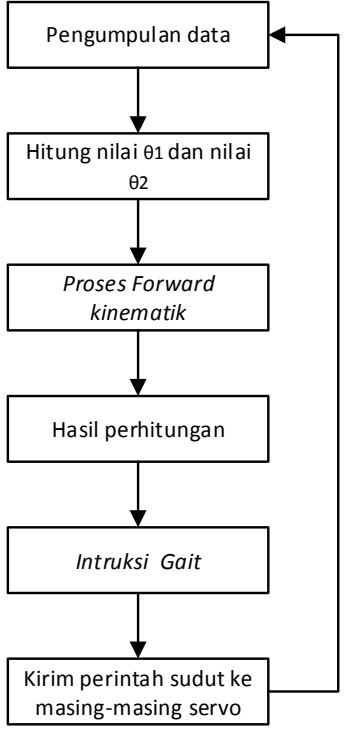

Gambar 2. alur pengembangan system

\section{Analisis forward kinematic}

Sistem ini mengimplementasikan hasil dari teori matematik geometri yang akan dipasang kerobot dengan menggunakan Arduino Mega128 sebagai alat proses dan otak sebagai pengendali. Sistem ini terdiri dari tiga kategori, pertama adalah Input sebagai masukan nilai sudut untuk menentukan koordinat gerak kaki robot dan algoritma pola gerak. Kedua adalah Proses, sebagai kalkulasi atau penghitung berikut pengontrol robot menggunakan Arduino Mega128, dan ketiga adalah Output sebagai penentu akhir proses yang dihasilkan oleh Arduino Mega128 yaitu gerakan berupa forward kinematik dengan pola langkah tripod gait. (Munadi, 2013; Arduino, 2015).

\section{Analisis Pola langkah (Gait)}

Gait adalah pola pergerakan dari sendi robot, dimana pergerakan ini meniru pergerakan mahluk hidup untuk bergerak baik itu pergerakan manusia contohnya pada robot Asimo atau pergerakan hewan seperti pada robot. Gait yang mencontoh pergerakan hewan digunakan dikarenakan pada 
kecepatan bergerak, kondisi Lingkungan, agilitasnya atau kelincahannya, dan kemampuan kelak-kloknya atau maneuverbility-nya, kepraktisan dan keefisiensi energi yang dibutuhkan. Pada robot berkaki ada beberapa pilihan kombinasi yang dapat diterapkan pada robot yaitu 2 kaki (bipedal), 4kaki (quardpod), atau 6 kaki (hexapod). Setelah terbentuk bagian kaki maka akan dibuat rekayasa pola gerak untuk menggerakan seluruh badan robot (Andrianto, 2013; Isvara, 2010; Munadi, 2013)

\section{HASIL DAN PEMBAHASAN}

\section{Sketsa Alur Sistem}

Sistem ini mengimplementasikan hasil dari teori matematik geometri yang akan dipasang kerobot dengan menggunakan Arduino MEGA128 sebagai alat proses dan otak sebagai pengendali. Sistem ini terdiri dari tiga katagori, pertama adalah Input sebagai masukan nilai sudut untuk menentukan koordinat gerak kaki robot dan algoritma pola gerak. Kedua adalah Proses, sebagai kalkulasi atau penghitung berikut pengontrol robot menggunakan Arduino MEGA128, dan ketiga adalah Output sebagai penentu akhir proses yang dihasilkan oleh Arduino MEGA128 yaitu gerakan berupa forward kinematik dengan pola langkah tripod gait (Kadir, 2016; Sanjaya, 2016).

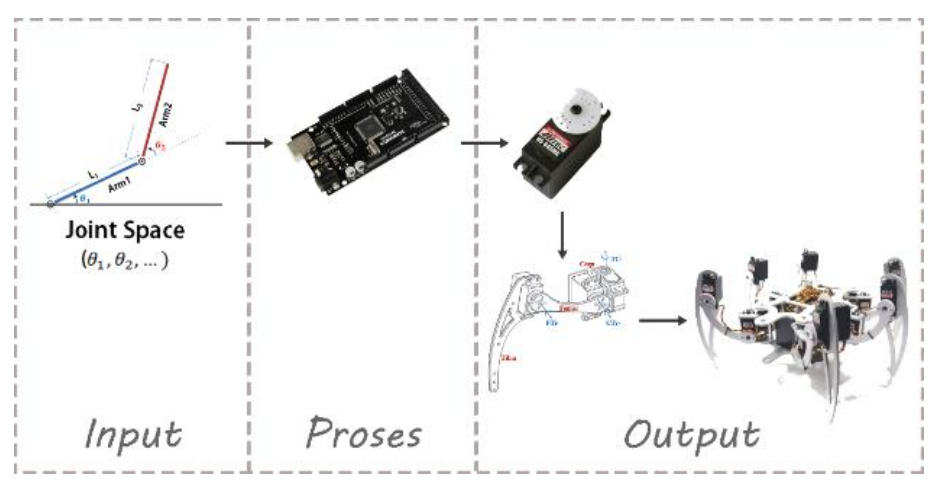

Gambar 3. Sketsa Alur Sistem

\section{Pengujian prinsip Kerja Sistem}

Prinsip kerja sistem dari penelitain ini yaitu saat pertama kali mikrokontroller robot diberi tegangan $9 \mathrm{~V}$ dan $12 \mathrm{~V}$ maka lampu indikator $L E D$ akan menyala dan robot siap bergerak karena sudah diberi logika pola gerak dengan dibantu sistem gerak kinematik maju (forward kinematic). Dengan logika pola gerak yang diberikan maka akan bergerak sesuai intruksi intruksi yang ada (Schilling, 1990; Syam, 2015)

Pembuatan desain software dalam suatu perangkat lunak tentunya harus mengutamakan cara kerja yang efisien dengan cara membuatkan desain flowchart sebagai berikut : 

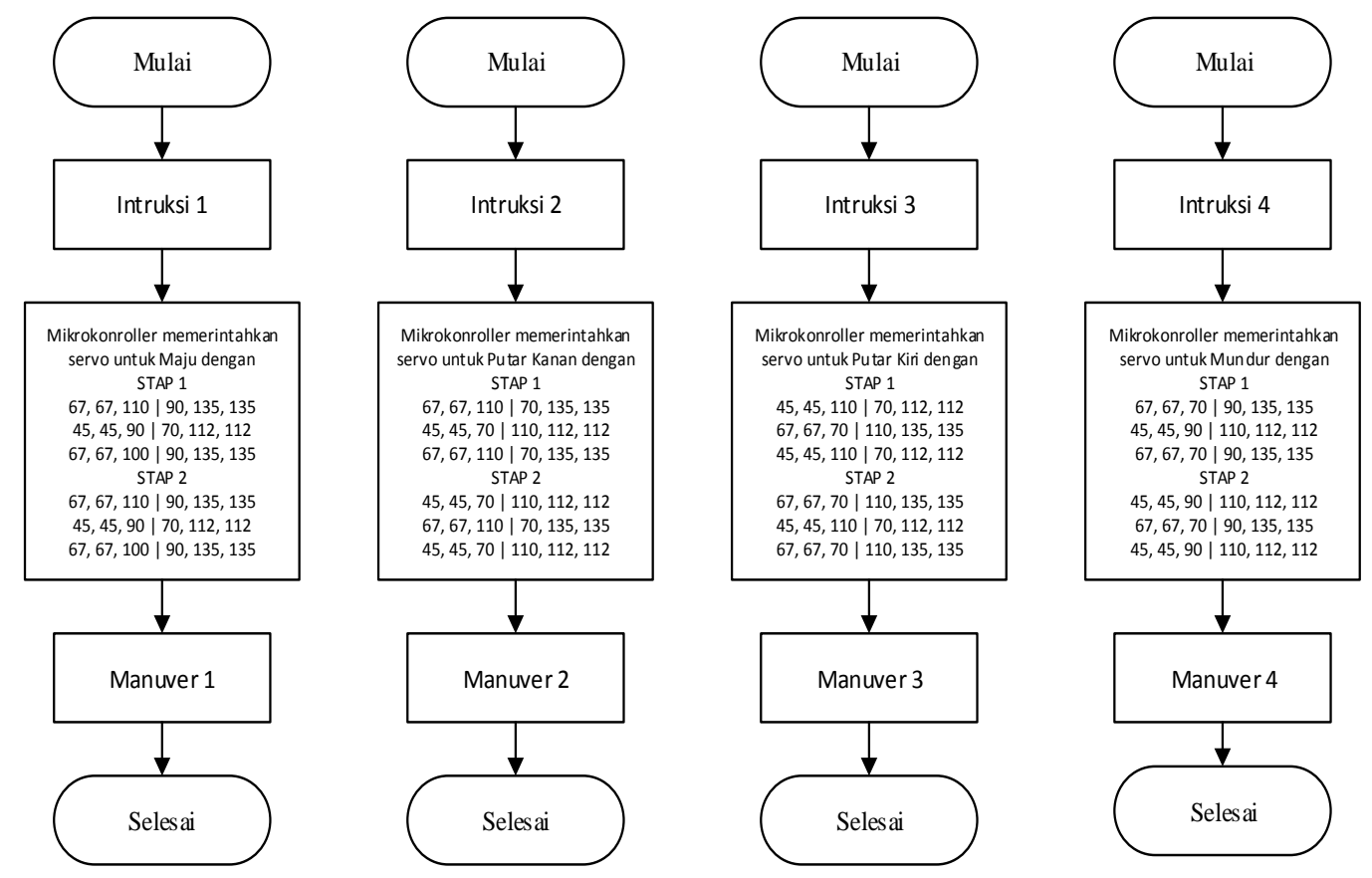

Gambar 4. Flowchart intruksi pola gerak

pada $x_{1}, x_{2}, y_{1}, y_{2}$, untuk menentukan bentuk kaki

Menentukan posisi sudut untuk semua kaki sebalah kiri dan kaki sebelah kanan robot saat berdiri pada intruksi 1. Dalam intruksi 1 dibagi menjadi 2 step dengan step pertama adalah pergerakan siklus pertama dan step kedua adalah untuk pergerakan siklus kedua (Mănoiu-Olaru, 2009; R, 2011; Schilling, 2000)

input servo $2=67^{\circ}$

input sudut servo 2

$=\left(90^{\circ}-\right.$ Servo 2$) * 1$

$=\left(90^{\circ}-67^{\circ}\right) * 1$

$=23^{\prime}$

$x_{1}=L_{1}, \cos \left(\theta_{1}\right)$

$x_{1}=3,2 \cdot \cos (23)$

$x_{1}=2,95$

$x_{2}=x_{1}+L_{2^{n}} \cos \left(\theta_{1}+\theta_{2}\right)$

$x_{2}=2,95+5,1, \cos (23+(-113))$

$x_{2}=2,95+5,1_{\mathrm{r}} \cos (-90)$

$x_{2}=2,95+0$

$x_{2}=2,95$ input servo $3=67^{\prime \prime}$

input sudut servo 3

$=-\left(\left(180^{\circ}-\right.\right.$ Servo 3$\left.) * 1\right)$

$=-\left(\left(180^{\circ}-67^{\circ}\right) * 1\right)$

$=-113^{\circ}$

$y_{1}=L_{1} \times \sin \left(\theta_{1}\right)$

$y_{1}=3,2 \times \sin (23)$

$y_{1}=1,25$

$y_{2}=y_{1}+L_{2} \times \sin \left(\theta_{1}+\theta_{2}\right)$

$y_{2}=1,25+5,1$. $\sin (23+(-11$ Gambar 5.Grafik forward kinematic intruksi 1

$y_{2}=1_{r} 25+5,1, \sin (-90)$

$y_{2}=1_{v} 25+(-5,1)$

$y_{2}=-3,85$

Dari hasil perhitungan diatas didapat nilai pada bagian kiri depan.
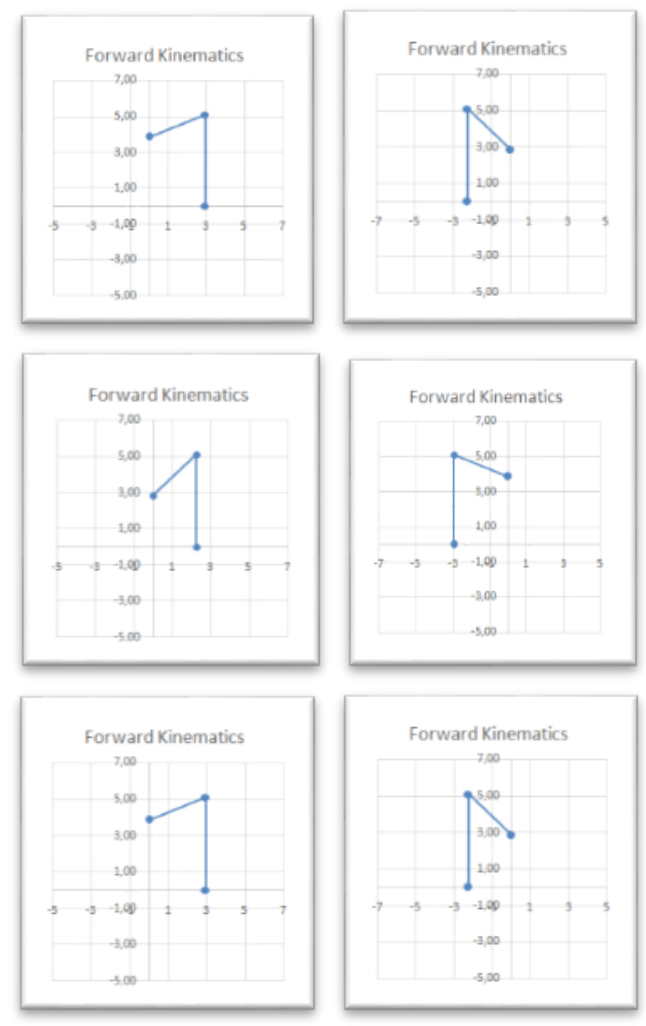

Setelah menentukan sudut pemasangan servo pada robot, barulah konsep pola berjalan bisa dilakukan untuk tahap pengujian selanjutnya yaitu posisi gerak awal adalah diam. 


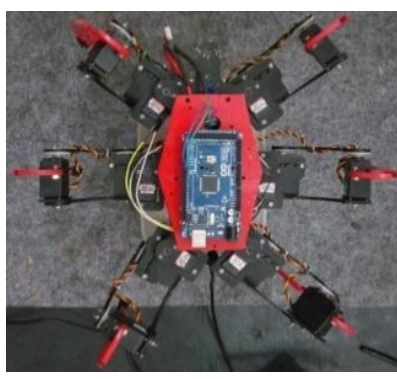

Gambar 6. Pengujian posisi awal pola langkah

Sesuai dengan konsep algoritma tripod gait yaitu bertumpu 3 kaki secara bergantian, pada proses ini robot akan menjalankan intruksi bagian kaki L2 (kiri tengah), R1 (kanan depan), R3 (kanan belakang), akan naik keatas, dan bagian kaki L1(kiri depan), R2 (kanan tengah), R3 (kiri belakang) untuk bergerak kelangkah berikutnya.

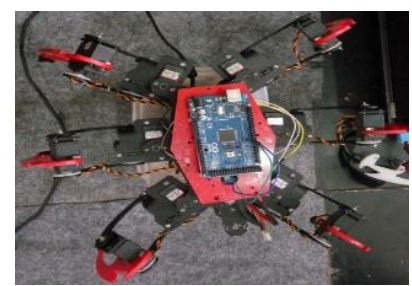

Gambar 7. Pengujian posisi awal instruksi 1 Step 1

Proses berikutnya adalah menggerakan bagian kaki L1 (kiri depan), R2 (kanan tengah), R3 (kiri belakang), bergerak ke belakang dengan perintah servo bagian bahu bergerak sebanyak $20^{\circ}$.

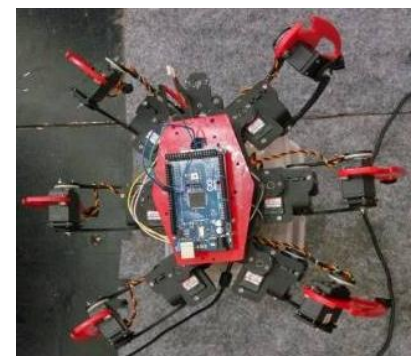

Gambar 8. Pengujian posisi awal instruksi 1 Step 2

Proses berikutnya adalah perpindahan tumpuan kaki dengan bagian kaki L1 (kiri depan), R2 (kanan tengah), R3 (kiri belakang), bergerak naik dan bagian kaki L2 (kiri tengah), R1 (kanan depan), R3 (kanan belakang) turun ke bawah menjadi tumpuan selanjutnya.

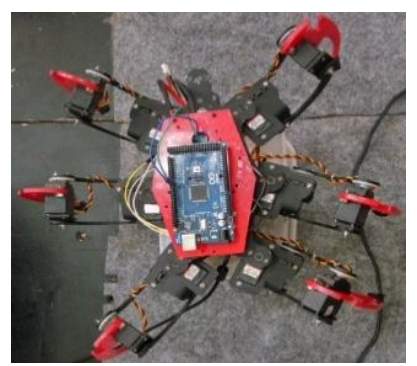

Gambar 9. Pengujian posisi awal instruksi 1 Step 3

Proses berikutnya adalah menggerakan bagian kaki R1 (kanan depan), L2 (kiri tengah), R3 (kanan belakang), bergerak ke belakang dengan perintah servo bagian bahu bergerak sebanyak $20^{\circ}$.

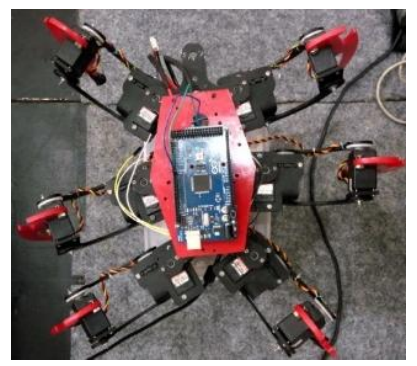

Gambar 10. Pengujian posisi awal instruksi 1 Step 4

\section{Pengujian Gerak Robot Hexapod}

Tahap ini dilakukan dengan tujuan untuk mengetahui sistem yang dibuat sudah bekerja dengan benar atau tidak. Kemudian menguji kemungkinan kesalahan yang dapat terjadi pada komponen-komponen yang diimplementasikan pada sistem ini. Output yang dihasilkan dari inputan pola gerak tripod gait yang diproses kedalam mikrokontroler menghasilkan pergerakan pola langkah manuver sesuai intruksi, pola langkah dasar tripod gait dapan menghasilkan manuver maju, putar kanan, mundur, putar kiri (Munadi,2013; Prasetya, 2014). 
Tabel 1. Pengujian Gerak robot Hexapod

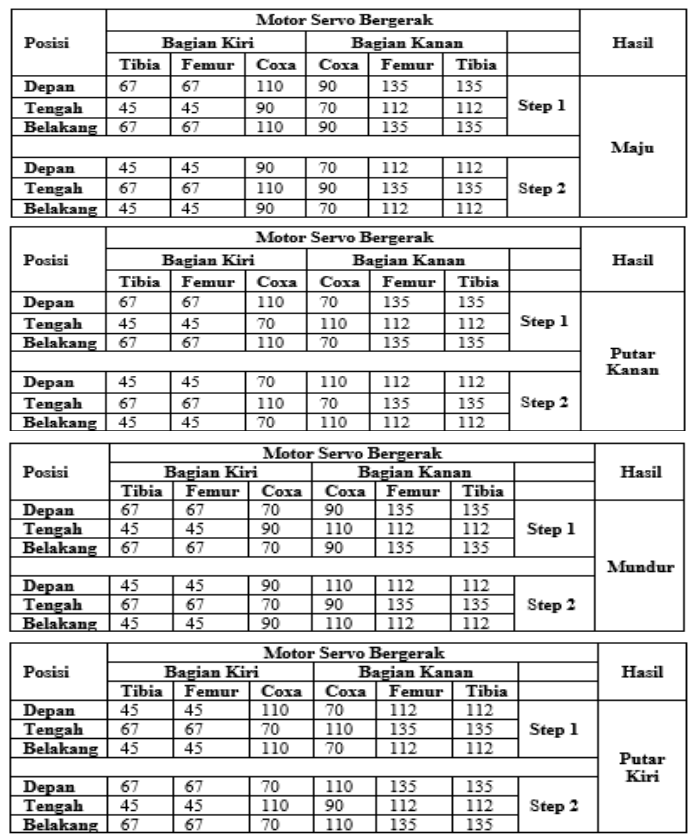

Dari tabel 1 dapat dijelaskan pada pengujian Gerak robot hexapod, dibagi menjadi dua bagian antara kaki bagain kiri dan kaki bagian kanan, tiap kaki memiliki bagian tertentu yaitu tibia (tumpu bawah), femur (penopang bahu), coxa (sendi bahu). Warna hijau menandakan posisi kaki sedang berada dibawah dan bergantian dalam langkahnya. Dari beberapa hasil percobaan robot dapat bergerak manuver maju, putar kanan, putar kiri, mundur.

\section{Pengujian Gerakan Maju}

Pada tahap ini pengujian robot hexapod dilakukan di lintasan sepanjang $200 \mathrm{~cm}$, dengan 2 pengujian kondisi permukaan yaitu area terbuka dan area tertutup, untuk dihitung kecepatan dan kemampuan gerak maju lurus robot (Sayuti, 2009; Schilling, 1990; Williams II, 2016)).

Pada pengujian gerakan maju pada area terbuka, kecepatan rata-rata robot adalah sebesar $4,44 \mathrm{~cm} / \mathrm{s}$ atau sekitar $0,04 \mathrm{~m} / \mathrm{s}$. Dan pada pengujian ini robot berhasil maju lurus pada jarak $200 \mathrm{~cm}$ dengan keberhasilan 100\% tanpa adanya galat.
Tabel 2. Pengujian Gerakan Maju pada Area Terbuka

\begin{tabular}{|c|c|c|c|c|}
\hline Pengujian & $\begin{array}{c}\text { Waktu } \\
\text { (Detik) }\end{array}$ & $\begin{array}{c}\text { Jarak } \\
(\mathrm{CM})\end{array}$ & $\begin{array}{c}\text { Kecepatan Robot } \\
(\mathrm{cm} / \mathrm{s})\end{array}$ & Hasil \\
\hline 1 & 43,2 & 200 & 4,63 & $\mathrm{~V}$ \\
\hline 2 & 45,6 & 200 & 4,39 & $\mathrm{~V}$ \\
\hline 3 & 42,8 & 200 & 4,67 & $\mathrm{~V}$ \\
\hline 4 & 48 & 200 & 4,17 & $\mathrm{~V}$ \\
\hline 5 & 47,6 & 200 & 4,20 & $\mathrm{~V}$ \\
\hline 6 & 44,3 & 200 & 4,51 & $\mathrm{~V}$ \\
\hline 7 & 46,5 & 200 & 4,30 & $\mathrm{~V}$ \\
\hline 8 & 42,9 & 200 & 4,66 & $\mathrm{~V}$ \\
\hline 9 & 46,4 & 200 & 4,31 & $\mathrm{~V}$ \\
\hline 10 & 43,5 & 200 & 4,60 & $\mathrm{~V}$ \\
\hline
\end{tabular}

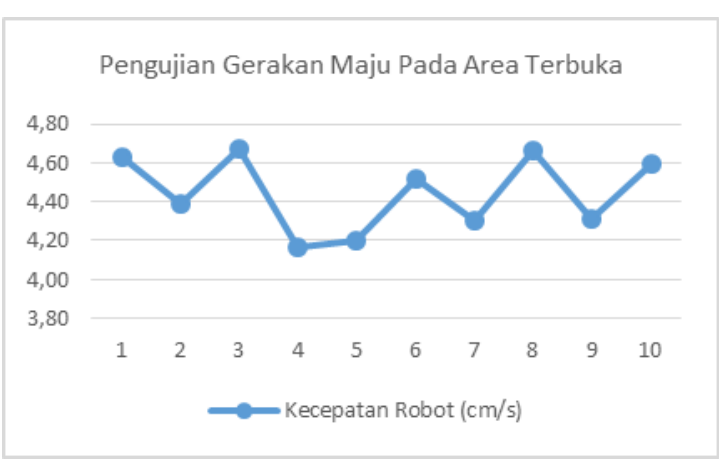

Gambar 11. Grafik Pengujian Gerakan Maju pada Area Terbuka

Tabel 3. Pengujian Gerakan Maju pada Area Tertutup

\begin{tabular}{|c|c|c|c|c|}
\hline Pengujian & $\begin{array}{c}\text { Waktu } \\
\text { (Detik) }\end{array}$ & $\begin{array}{c}\text { Jarak } \\
\text { (CM) }\end{array}$ & $\begin{array}{c}\text { Kecepatan Robot } \\
\mathrm{cm} / \mathrm{s}\end{array}$ & Hasil \\
\hline 1 & 34 & 200 & 5,88 & $\mathrm{~V}$ \\
\hline 2 & 36,2 & 200 & 5,52 & $\mathrm{~V}$ \\
\hline 3 & 35,7 & 200 & 5,60 & $\mathrm{~V}$ \\
\hline 4 & 38 & 200 & 5,26 & $\mathrm{~V}$ \\
\hline 5 & 34,6 & 200 & 5,78 & $\mathrm{~V}$ \\
\hline 6 & 37,5 & 200 & 5,33 & $\mathrm{~V}$ \\
\hline 7 & 35 & 200 & 5,71 & $\mathrm{~V}$ \\
\hline 8 & 37,9 & 200 & 5,28 & $\mathrm{~V}$ \\
\hline 9 & 34,3 & 200 & 5,83 & $\mathrm{~V}$ \\
\hline 10 & 36,8 & 200 & 5,43 & $\mathrm{~V}$ \\
\hline
\end{tabular}

Pada pengujian gerakan maju pada area tertutup, kecepatan rata-rata robot adalah sebesar $5,56 \mathrm{~cm} / \mathrm{s}$ atau sekitar $0,05 \mathrm{~m} / \mathrm{s}$. Dan pada pengujian ini robot berhasil maju lurus pada jarak $200 \mathrm{~cm}$ dengan keberhasilan 100\% tanpa adanya galat.

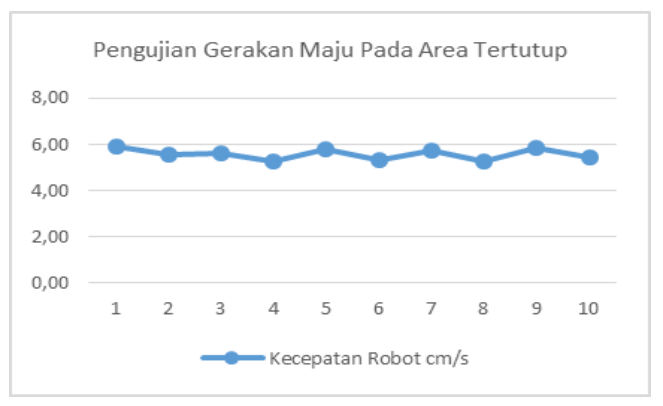

Gambar 12. Grafik Pengujian Gerakan Maju pada Area Tertutup 
Tabel 4. Pengujian Gerakan Mundur pada Area Terbuka

\begin{tabular}{|c|c|c|c|c|}
\hline Pengujian & $\begin{array}{c}\text { Waktu } \\
\text { (Detik) }\end{array}$ & $\begin{array}{c}\text { Jarak } \\
\text { (CM) }\end{array}$ & $\begin{array}{c}\text { Kecepatan Robot } \\
\text { (cm/s) }\end{array}$ & Hasil \\
\hline 1 & 46,5 & 200 & 4,301 & $\mathrm{~V}$ \\
\hline 2 & 47 & 200 & 4,255 & $\mathrm{~V}$ \\
\hline 3 & 46,3 & 200 & 4,320 & $\mathrm{~V}$ \\
\hline 4 & 48,6 & 200 & 4,115 & $\mathrm{~V}$ \\
\hline 5 & 49,5 & 200 & 4,040 & $\mathrm{~V}$ \\
\hline 6 & 52 & 200 & 3,846 & $\mathrm{~V}$ \\
\hline 7 & 50,3 & 200 & 3,976 & $\mathrm{~V}$ \\
\hline 8 & 49,7 & 200 & 4,024 & $\mathrm{~V}$ \\
\hline 9 & 46,9 & 200 & 4,264 & $\mathrm{~V}$ \\
\hline 10 & 46 & 200 & 4,348 & $\mathrm{~V}$ \\
\hline
\end{tabular}

Pada pengujian gerakan mundur pada area terbuka, kecepatan rata-rata robot adalah sebesar $4,15 \mathrm{~cm} / \mathrm{s}$ atau sekitar $0,04 \mathrm{~m} / \mathrm{s}$. Dan pada pengujian ini robot berhasil mundur lurus pada jarak $200 \mathrm{~cm}$ dengan keberhasilan 100\% tanpa adanya galat.

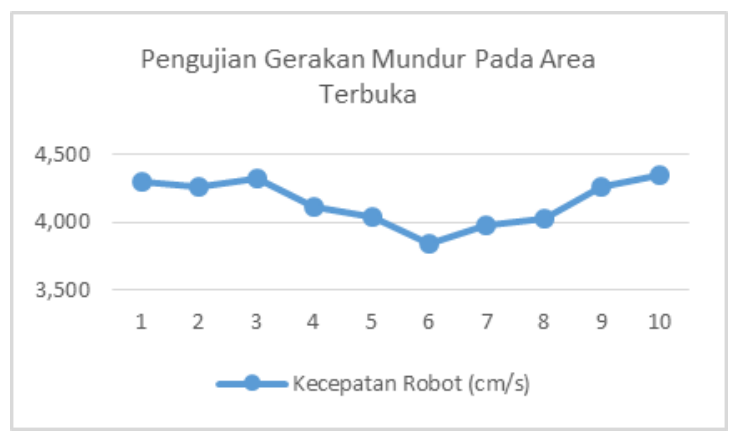

Gambar 13. Grafik Pengujian Gerakan Mundur pada Area Terbuka.

Tabel 5. Pengujian Gerakan Mundur pada Area Tertutup

\begin{tabular}{|c|c|c|c|c|}
\hline Pengujian & $\begin{array}{c}\text { Waktu } \\
\text { (Detik) }\end{array}$ & $\begin{array}{c}\text { Jarak } \\
(\mathrm{CM})\end{array}$ & $\begin{array}{c}\text { Kecepatan Robot } \\
(\mathrm{cm} / \mathrm{s})\end{array}$ & Hasil \\
\hline 1 & 43,8 & 200 & 4,57 & $\mathrm{~V}$ \\
\hline 2 & 45,7 & 200 & 4,38 & $\mathrm{~V}$ \\
\hline 3 & 42 & 200 & 4,76 & $\mathrm{~V}$ \\
\hline 4 & 43,6 & 200 & 4,59 & $\mathrm{~V}$ \\
\hline 5 & 46,2 & 200 & 4,33 & $\mathrm{~V}$ \\
\hline 6 & 42,9 & 200 & 4,66 & $\mathrm{~V}$ \\
\hline 7 & 46,3 & 200 & 4,32 & $\mathrm{~V}$ \\
\hline 8 & 44,7 & 200 & 4,47 & $\mathrm{~V}$ \\
\hline 9 & 47 & 200 & 4,26 & $\mathrm{~V}$ \\
\hline 10 & 43,5 & 200 & 4,60 & $\mathrm{~V}$ \\
\hline
\end{tabular}

Pada pengujian gerakan mundur area tertutup, kecepatan rata-rata robot adalah sebesar $4,49 \mathrm{~cm} / \mathrm{s}$ atau sekitar $0,04 \mathrm{~m} / \mathrm{s}$. Dan pada pengujian ini robot berhasil mundur lurus pada jarak $200 \mathrm{~cm}$ dengan keberhasilan $100 \%$ tanpa adanya galat.

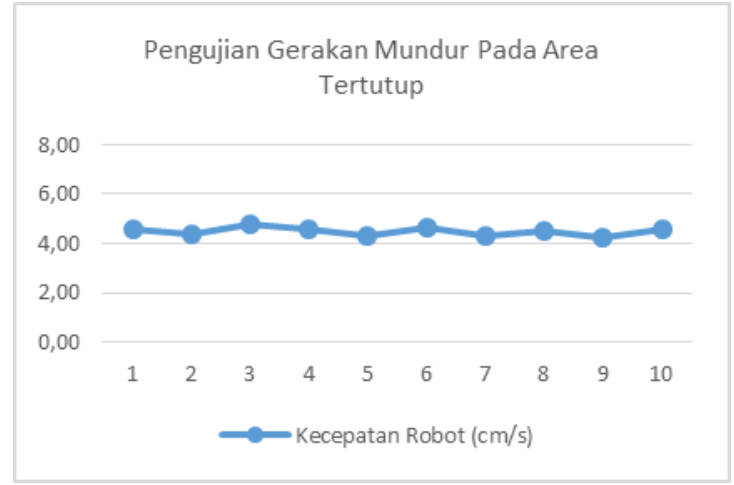

Gambar 14. Pengujian Gerakan Mundur Area Tertutup

Tabel 6. Pengujian Berputar Kanan Area Terbuka

\begin{tabular}{|c|c|c|c|c|}
\hline Pengujian & $\begin{array}{c}\text { Waktu } \\
\text { (Detik) }\end{array}$ & $\begin{array}{c}\text { Sudut } \\
\text { (derajat) }\end{array}$ & $\begin{array}{c}\text { Kecepatan Robot } \\
\text { Derajat/s }\end{array}$ & Hasil \\
\hline \multirow{2}{*}{1} & 3,3 & 45 & 13,64 & $\mathrm{~V}$ \\
\cline { 2 - 5 } 2 & 3,6 & 45 & 12,50 & $\mathrm{~V}$ \\
\cline { 2 - 5 } 3 & 3,7 & 45 & 12,16 & $\mathrm{~V}$ \\
\hline 1 & 6,7 & 90 & 13,43 & $\mathrm{~V}$ \\
\cline { 2 - 5 } 2 & 7,1 & 90 & 12,68 & $\mathrm{~V}$ \\
\cline { 2 - 5 } 3 & 7,3 & 90 & 12,33 & $\mathrm{~V}$ \\
\hline 1 & 13,5 & 180 & 13,33 & $\mathrm{~V}$ \\
\cline { 2 - 5 } 2 & 14,2 & 180 & 12,68 & $\mathrm{~V}$ \\
\cline { 2 - 5 } 3 & 13,8 & 180 & 13,04 & $\mathrm{~V}$ \\
\hline
\end{tabular}

Kecepatan rata-rata robot untuk berputar ke kanan dengan sudut $180^{\circ}$ membutuhkan waktu sekitar 13,02 derajat/detik. Robot ini selalu berhasil dalam melakukan gerakan berputar dengan keberhasilan $100 \%$ tanpa galat.

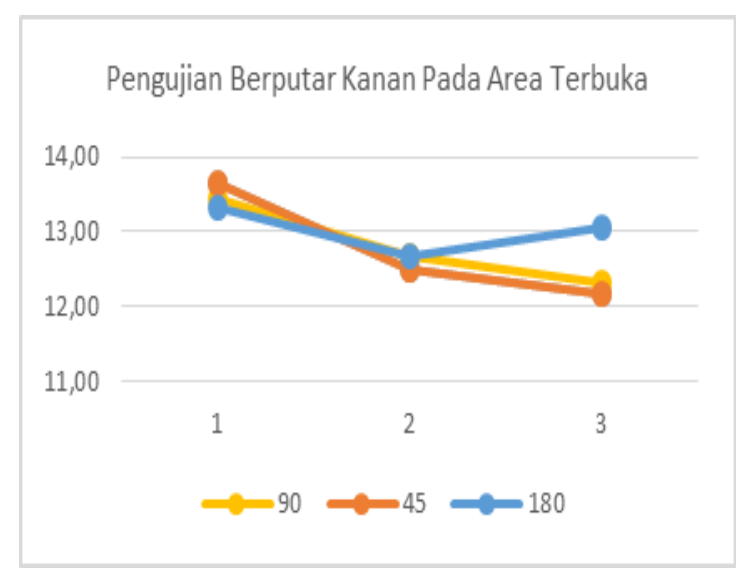

Gambar 15. Grafik Pengujian Gerakan Berputar Kanan pada Area Terbuka 
Tabel 7. Pengujian Berputar Kanan pada Area Tertutup

\begin{tabular}{|c|c|c|c|c|}
\hline Pengujian & $\begin{array}{c}\text { Waktu } \\
\text { (Detik) }\end{array}$ & $\begin{array}{c}\text { Sudut } \\
\text { (derajat) }\end{array}$ & $\begin{array}{c}\text { Kecepatan } \\
\text { Robot } \\
\text { Derajat/s }\end{array}$ & Hasil \\
\hline \multirow{2}{*}{1} & 3,2 & 45 & 14,06 & $\mathrm{~V}$ \\
\cline { 2 - 5 } 2 & 3,4 & 45 & 13,24 & $\mathrm{~V}$ \\
\cline { 2 - 5 } 3 & 3,1 & 45 & 14,52 & $\mathrm{~V}$ \\
\hline \multirow{2}{*}{2} & 6,3 & 90 & 14,29 & $\mathrm{~V}$ \\
\cline { 2 - 5 } 2 & 6,5 & 90 & 13,85 & $\mathrm{~V}$ \\
\cline { 2 - 5 } 3 & 6,4 & 90 & 14,06 & $\mathrm{~V}$ \\
\hline \multirow{2}{*}{2} & 13 & 180 & 13,85 & $\mathrm{~V}$ \\
\cline { 2 - 5 } 3 & 13,1 & 180 & 13,74 & $\mathrm{~V}$ \\
\cline { 2 - 5 } 3 & 12,9 & 180 & 13,95 & $\mathrm{~V}$ \\
\hline
\end{tabular}

Kecepatan rata-rata robot untuk berputar ke kanan dengan sudut $180^{\circ}$ membutuhkan waktu sekitar 13,85 derajat/detik. Robot ini selalu berhasil dalam melakukan gerakan berputar dengan keberhasilan $100 \%$ tanpa galat.

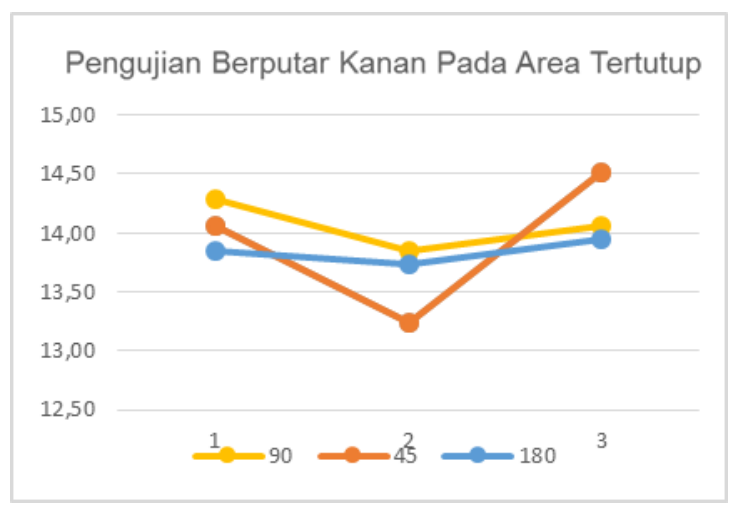

Gambar 16. Grafik Pengujian Gerakan Berputar Kanan pada Area Tertutup

Tabel 8.Pengujian Berputar Kiri pada Area Terbuka

\begin{tabular}{|c|c|c|c|c|}
\hline Pengujian & $\begin{array}{c}\text { Waktu } \\
\text { (Detik) }\end{array}$ & $\begin{array}{c}\text { Sudut } \\
\text { (derajat) }\end{array}$ & $\begin{array}{c}\text { Kecepatan Robot } \\
\text { Derajat/s }\end{array}$ & Hasil \\
\hline \multirow{2}{*}{1} & 3,4 & 45 & 13,24 & $\mathrm{~V}$ \\
\cline { 2 - 5 } 2 & 3,6 & 45 & 12,50 & $\mathrm{~V}$ \\
\cline { 2 - 5 } 3 & 3,5 & 45 & 12,86 & $\mathrm{~V}$ \\
\hline \multirow{2}{*}{1} & 6,9 & 90 & 13,04 & $\mathrm{~V}$ \\
\cline { 2 - 5 } 2 & 7,3 & 90 & 12,33 & $\mathrm{~V}$ \\
\cline { 2 - 5 } 3 & 7,1 & 90 & 12,68 & $\mathrm{~V}$ \\
\hline 1 & 13,7 & 180 & 13,14 & $\mathrm{~V}$ \\
\cline { 2 - 5 } 2 & 13,7 & 180 & 13,14 & $\mathrm{~V}$ \\
\cline { 2 - 5 } 3 & 14,4 & 180 & 12,50 & $\mathrm{~V}$ \\
\hline
\end{tabular}

Kecepatan rata-rata robot untuk berputar ke kiri dengan sudut $180^{\circ}$ membutuhkan waktu sekitar 12,93 derajat/detik. Robot ini selalu berhasil dalam melakukan gerakan berputar dengan keberhasilan 100\% tanpa galat.
Pengujian Berputar Kiri Pada Area Terbuka

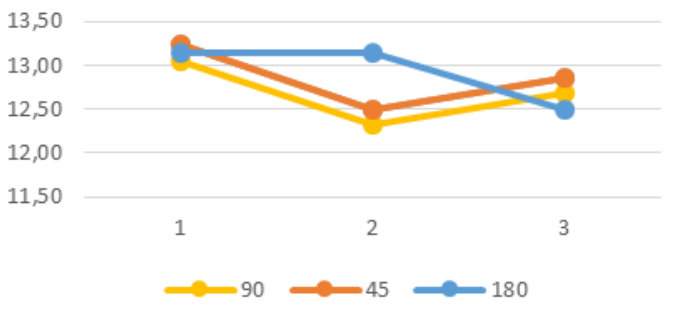

Gambar 17. Grafik Pengujian Gerakan Berputar Kiri pada Area Terbuka

Tabel 9. Pengujian Berputar Kiri pada Area Tertutup

\begin{tabular}{|c|c|c|c|c|}
\hline Pengujian & $\begin{array}{c}\text { Waktu } \\
\text { (Detik) }\end{array}$ & $\begin{array}{c}\text { Sudut } \\
\text { (derajat) }\end{array}$ & $\begin{array}{c}\text { Kecepatan } \\
\text { Robot } \\
\text { Derajat/s }\end{array}$ & Hasil \\
\hline \multirow{2}{*}{1} & 3,5 & 45 & 12,86 & $\mathrm{~V}$ \\
\cline { 2 - 5 } 2 & 3,6 & 45 & 12,50 & $\mathrm{~V}$ \\
\cline { 2 - 5 } 3 & 3,5 & 45 & 12,86 & $\mathrm{~V}$ \\
\hline 1 & 7,2 & 90 & 12,50 & $\mathrm{~V}$ \\
\cline { 2 - 5 } 2 & 6,9 & 90 & 13,04 & $\mathrm{~V}$ \\
\cline { 2 - 5 } 3 & 7,1 & 90 & 12,68 & $\mathrm{~V}$ \\
\hline 1 & 14,1 & 180 & 12,77 & $\mathrm{~V}$ \\
\cline { 2 - 5 } 2 & 14 & 180 & 12,86 & $\mathrm{~V}$ \\
\cline { 2 - 5 } 3 & 14,2 & 180 & 12,68 & $\mathrm{~V}$ \\
\hline
\end{tabular}

Kecepatan rata-rata robot untuk berputar ke kiri dengan sudut $180^{\circ}$ membutuhkan waktu sekitar 12,77 derajat/detik. Robot ini selalu berhasil dalam melakukan gerakan berputar dengan keberhasilan $100 \%$ tanpa galat.

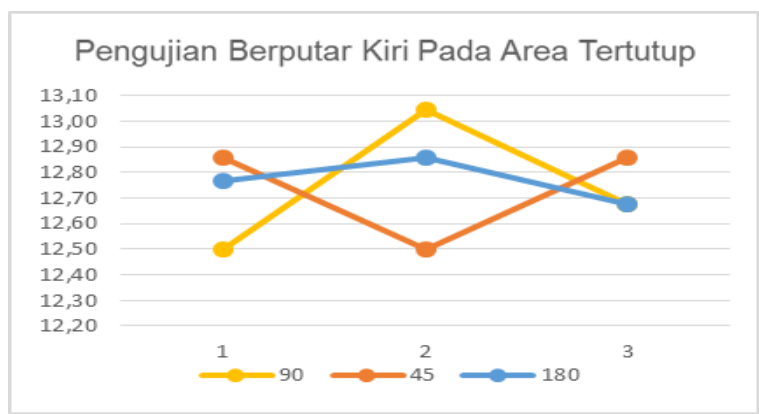

Gambar 18. Grafik Pengujian Gerakan Berputar Kiri pada Area Tertutup

Tabel 10. Pengujian pada Area Tertutup :

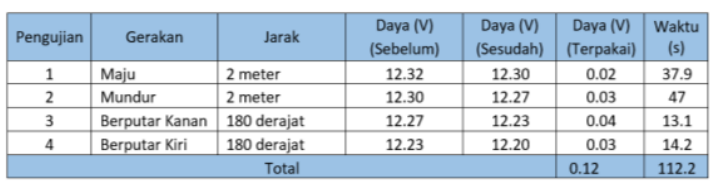


Tabel 11. Pengujian pada Area Terbuka :

\begin{tabular}{|c|l|l|c|c|c|c|}
\hline Pengujian & \multicolumn{1}{|c|}{ Perintah } & \multicolumn{1}{|c|}{ Jarak } & $\begin{array}{c}\text { Daya }(\mathrm{V}) \\
\text { (Sebelum) }\end{array}$ & $\begin{array}{c}\text { Daya }(\mathrm{V}) \\
\text { (Sesudah) }\end{array}$ & $\begin{array}{c}\text { Daya }(\mathrm{V}) \\
\text { (Terpakai) }\end{array}$ & $\begin{array}{c}\text { Waktu } \\
\text { (s) }\end{array}$ \\
\hline 1 & Maju & 2 meter & 12.20 & 12.14 & 0.06 & 48 \\
\hline 2 & Mundur & 2 meter & 12.14 & 12.08 & 0.05 & 52 \\
\hline 3 & Berputar Kanan & 180 derajat & 12.08 & 12.05 & 0.03 & 14.2 \\
\hline 4 & Berputar Kiri & 180 derajat & 12.05 & 12.01 & 0.04 & 14.4 \\
\hline \multicolumn{5}{|c|}{ Total } \\
\hline
\end{tabular}

\section{PENUTUP}

Dari hasil pembahasan penelitian yang telah ada pada bab sebelumnya, maka dalam penelitian ini dapat diambil kesimpulan sebagai berikut:

1. Dengan menerapkan forward kinematik pada robot hexapod dapat mengetahui bentuk kaki jika diinputkan nilai sudut yang diproses olah Arduino Mega128 pada motor servo.

2. Dengan menerapkan tripod gait pada robot hexapod dapat menghasilkan manuver yang berbeda yaitu, maju, putar kanan, putar kiri, mundur.

3. Pada pengujian gerakan maju pada area terbuka dengan kecepatan rata-rata $4,44 \mathrm{~cm} / \mathrm{s}$, pengujian gerakan maju pada area tertutup dengan kecepatan rata-rata $5,56 \mathrm{~cm} / \mathrm{s}$,

4. Pengujian gerakan mundur pada area terbuka dengan kecepatan rata-rata $4,15 \mathrm{~cm} / \mathrm{s}$, Pengujian gerakan mundur pada area tertutup dengan kecepatan rata-rata $4,49 \mathrm{~cm} / \mathrm{s}$, Pengujian gerakan berputar kanan pada terbuka dengan kecepatan rata-rata 13,02 derajat/detik, Pengujian gerakan berputar kanan pada tertutup dengan kecepatan rata-rata 13,85 derajat/detik, pengujian gerakan berputar kiri pada terbuka dengan kecepatan rata-rata 12,93 derajat/detik, pengujian gerakan berputar kiri pada tertutup dengan kecepatan rata-rata 12,77 derajat/detik. Daya yang dibutuhkan keseluruhan pengujian pada area tertutup adalah 0.12 Volt dengan durasi pakai 112.2 detik dan di area terbuka adalah 0.18 Volt dengan durasi pakai 128.6 detik.

\section{UCAPAN TERIMA KASIH}

Saya ucapkan terima kasih banyak kepada Program Studi Ilmu Komputer FMIPA Universitas Pakuan, atas dukungan proses riset secara keseluruhan dan penyediaan laboratorium untuk proses pengolahan dan analisis data. Terima kasih juga kepada Laboratorium Workshop ROBOTIK Ilmu Komputer Universitas Pakuan atas dukungan koordinasi serta fasilitasi sampai penelitian ini penulis selesaikan. Serta Program studi magister komputer universitas Budi Luhur Jakarta yang telah membantu dalam dukungan koordinasi penyelesaian penelitian ini.

\section{DAFTAR PUSTAKA}

Andrianto, H. (2013). Pemrograman Mikrokontroler AVR ATmegal6 Menggunakan Bahasa C. UK. Bandung: Maranatha, Elektro.

Arduino. (2015). Datasheet Arduino Mega. Italy. Budiharto, W. (2010). Robotika - Teori dan Implementasi. Yogyakarta: CV Andi Offset.

Budiharto, W. (2014). Robotika Modern - Teori dan Implementasi (Edisi Revi). Yogyakarta: CV Andi Offset.

Dwi, Taufiq, S. . (2010). Buku Pintar Robotika. Yogyakarta: CV Andi Offset.

Harsono, Djiwo., Budi Suhendro, R. L. (2012). Rancang Bangun Robot Hexapod dengan Kedali Jarak Jauh. Sekolah Tinggi Teknologi Nuklir - Badan Tenaga Nuklir Nasional.

Isvara, Yudi, Dinara Enggar Prabakti, W. P. (2010). Algoritma Tripod Gait dan Kinematika Balikan pada Robot Hexapod. Institut Teknologi Bandung.

Kadir, A. (2016). Simulasi Arduino. Jakarta: PT Elex Media Komputindo. 
Mănoiu-Olaru, N. (2009). Basic Walking Simulations and Gravitational Stability Analysis for a Hexapod Robot Using Matlab. University of Craiova, Romania.

Munadi. (2013). Analisa Forward Kinematic Pada Simulator Arm Robot 5 Dof Yang Mengintegrasikan Mikrokontroler ArduinoUno Dan Labview. Universitas Diponegoro.

Munir, R. (2011). Algoritma dan Pemrograman dalam bahasa Pascal dan C (Edisi Revi). Bandung: Informatika.

Prasetya, Dody, K. P. (2014). Gerak Robot Berkaki Enam Menggunakan 3 Servo dan Sensor Jarak. Institut Pertanian Bogor.

Purwanto. (2009). Definisi dan Spesifikasi Motor Servo Hitec MG.

R, W. (2011). Simulating the "first steps" of a walking hexapod robot. University of Technology Eindhoven.
Sanjaya, M. (2016). Panduan Praktis Membuat Robot Cerdas Menggunakan Arduino dan $M A T L A B$. Yogyakarta: CV Andi Offset.

Sayuti, F. M. (2009). Robot Visi. Yogyakarta. Yogyakarta: Graha Ilmu.

Schilling. (1990). Fundamentals of robotics: analysis and control. New Jersey, USA: Prentice Hall.

Schilling. (2000). Definisi dan Penjelasan dasar menegenai robot. USA.

Setiawan, Surya, Firdaus, Budi Rahmadya, D. (2015). Penerapan Invers Kinematika Untuk Pergerakan Kaki Robot Biped. Universitas Andalas.

Syam, R. (2015). Kinematika dan Dinamika Robot Lengan. Universitas Hasanuddin.

Williams II, R. . (2016). The Delta Parallel Robot: Kinematics SolutionsNo Title. Ohio University. 